\title{
Primus inter pares - paradokser, deadlocks og omveje i gymnasieledelse
}

\author{
Alice Juel Jacobsen \& Anders Buch
}

I denne artikel undersøger vi organisatoriske reformforandringer, som de konstrueres i interaktionen mellem ledere og lærere i skolesammenhæng. Det empiriske grundlag er casestudier i danske gymnasieskoler. Ved at benytte en etnografisk fremgangsmåde og et paradoksbegreb knyttet til en forståelse af professioner, undersøges mikroprocesserne, der er i spil i New Public Management-forandringer i skoleregi. I artiklen viser vi, at en position som primus inter paresleder imellem de professionelle fører til adskillige paradokser, blokeringer og omveje, alle med effekt for arbejdet med forandringer i skolen. Konkrete paradokser identificeres ud fra det empiriske materiale, og primus inter pares-ledelsens udfordringer udfoldes.

\section{Indledning}

R eform af den offentlige sektor har været Rå dagsordenen i Danmark såvel som i mange andre vestlige lande $i$ de sidste to til tre årtier. New Public Management (NPM) har haft store implikationer for institutionsledere og mere generelt for professionelle, der beskæftiger sig med forandringerne og skal skabe nye offentlige organisationer (Farrel og Morris 2003, 136) ${ }^{1}$. Denne artikel fokuserer på relationerne mellem ledere og medarbejdere i gymnasiet ved at se på de konkrete praksisstrategier, som udfoldes i det organisatoriske hverdagsliv, der følger af forandringskravene. Artiklens empiriske grundlag er to danske skoler, som studeres i forbindelse med implementering af gymnasiereformen i 2005 (Undervisningsministeriet 2004a, 2004b). Artiklen udgør kort sagt udfordringerne og implikationerne for aktørerne, der er med til at oversætte NPMforandringerne til praksis. Indledningsvist følger en kort introduktion til gymnasiereformens konkrete krav og forandringstemaer.

Ifølge Michael Power kan NPM-ideerne karakteriseres som en serie af overlappende elementer, som skal reorganisere den offentlige sektor fra et liberalt og rationelt afsæt:

"It emphasises cost control, financial transparency, the atomization of organizational sub units, the decentralization of management autonomy, (...) and enhancement of accountability to customers for the quality of service via creation of performance indicators." (Power 1997, 43). 
Disse udviklingstræk genfindes i gymnasiereformen som centrale elementer i den strategiske målretning af gymnasiet. Udgangspunktet for reformen er et nyt syn på viden og uddannelse som det vigtigste konkurrenceparameter i det globale videnssamfund. Fornyelse af fagligheden i gymnasiet mod tværfaglighed står centralt i reformen. Denne fornyelse får konsekvenser for skolen på organisationsniveau. Lærersamarbejdet bliver en uomgængelig og ny del af lærerrollen, samtidig med at der skal etableres teamstrukturer i gymnasiet (Undervisningsministeriet 2005). I forbindelse hermed beskrives et nyt værktøj, studieplanen, som skal udfyldes af lærerteamet, sådan at den kan udgøre en kontinuerlig ramme for arbejdet (Undervisningsministeriet 2005, 17). Studieplanen er samtidig kombineret med forpligtelser til intern, løbende evaluering og ekstern dokumentation. For lærernes vedkommende sættes den individuelle og autonome rolle kort sagt under pres. Reformen udfordrer samtidig lærernes autonomi med kontrolelementer, som er knyttet til kravene om evaluering og dokumentation af målopfyldelsen af arbejdet. På ledelsessiden skitseres det, at ledelsen skal træde i karakter, blive superviserende og personaleledende: "Nøgleordene $i$ forholdet mellem ledelse og team er synlighed, supervision og sparring." (Undervisningsministeriet 2005, 15). En lang tradition for driftsledelse i gymnasiet skal ændres til synlig og målsættende ledelse. Samlet set kan arbejdet i gymnasiet ikke længere blot udføres gennem forvaltning af professionel faglig viden, hverken på leder- eller medarbejderniveau. Man kan sige, at skolen med reformen bevæger sig hen imod at blive en organisation, som er langt mere styrbar og matcher den offentlige sektors øvrige tilpasning til NPM-tænkning (Dahler-Larsen 2001, 79). Det er denne organisatoriske forandring, som er igangsat med Gymnasiere- form 2005, der udgør afsættet for studiet af skolernes interne komplekse og nuancerede processer.

Et gennemgående argument i national såvel som international forskning har i de senere år været, at offentlig ledelse bevæger sig i retning af en professionalisering, dvs. fra faglig ledelse mod generalistledelse, og det diskuteres hvorvidt nuværende mere fagligt orienterede ledere er i stand til at løfte ledelsesopgaven i forbindelse med forandringsudfordringerne i velfærdssektoren (Voxsted 2008; 2010). Som det så ofte er tilfældet i skolerne, er ledelsen i case-skolerne rekrutteret blandt lærerne efter primus inter pares-princippet, dvs. de bedste blandt ligestillede (Greenleaf 2003; Klausen 2006). De er altså forhenværende lærere med den samme uddannelsesmæssige baggrund som skolens medarbejdere. Artiklen viser, at en position som primus inter pares-leder blandt lærerne sætter modsætningsfyldte interaktioner i spil. I tilknytning hertil kan en række konkrete paradokser desuden identificeres. Primus inter pares-positionen skaber ikke blot uforudsete begrænsninger i ledelsesarbejdet, men forstærker organisatoriske modsætningsforhold. Grundlæggende set opstår og forstærkes organisatoriske paradokser, når ledelsen undgår at lede af hensyn til lærernes autonomi i de nye samarbejdsprocesser. Samtidig udtrykker lærerne deres behov for ledelse i forsøget på at opfylde reformens forventningskrav. De professionelles implementering af NPMreformen er i praksis afgørende for reformers virkning, både i omfang og karakter (Kragh Jespersen 2005; Røvik 2007; Scott 2008). Det bliver dermed vigtigt at skabe detaljeret viden om professionelles tolkning og håndtering af de udfordringer, som NPM-reformer indebærer for deres daglige arbejdsliv. Artiklens overordnede formål er altså at undersøge de organisatoriske forandringer, som de konstrueres i interaktionen 
mellem ledere og lærere i deres arbejdspraksisser. Ved at benytte en etnografisk tilgang og et paradoksbegreb bidrager artiklen med en ny viden gennem en fortolkning og forståelse af ledelse af lærere i skolen.

Som afsæt for artiklen sættes i følgende afsnit fokus på hidtidig dansk gymnasieforskning i organisation og ledelse med henblik på at præcisere denne artikels bidrag til feltet yderligere. Efterfølgende fremlægges autonomiforståelsen af professionelles roller, således som den beskrives i den klassiske litteratur, og især som den har udviklet sig i nyere sociologisk teori (Alvesson 2004; Adler m.fl. 2008; Kragh Jespersen 2012; Noordegraaf 2006; 2007; 2012; Thorup Larsen 2013). Formålet med dette afsnit er at opsummere forskningslitteraturens forståelse af professionel praksis som baggrund for artiklens empiriske analyse. I det tredje afsnit præsenteres de undersøgelsesmetoder, hvormed der er opnået indsigt i mønstrene for interaktioner mellem ledere og medarbejdere i analysen. I det fjerde afsnit formidles resultaterne af undersøgelsesarbejdet. I det femte og sidste afsnit diskuteres de bredere, mere vidtrækkende implikationer af artiklens fund.

\section{Hidtidig gymnasieforskning i organisation og ledelse}

Den hidtidige forskning i organisation og ledelse på gymnasieområdet har primært taget udgangspunkt i klassiske organisationsforandringsteorier. Kulturperspektivet har været centralt i designet bag en række nyere undersøgelsesarbejder (Gleerup og Wiedemann 2001; Gottlieb og Hornstrup 1998; Senger 2003; Wiedemann 2002). Mange studier har desuden været centreret om det almene gymnasium. Ulla Senger har, bl.a. med afhandlingen Organisatorisk loering og loererprofessionalisme i gymnasiet, bidraget med kulturanalyse $\mathrm{i}$ to forskel- lige almene gymnasier. Analysen udpeger blinde pletter i kulturen, der modvirker en eksternt ønsket dynamisering (Senger 2003). Et enkelt studie tematiserer forskelle i de tre skoletyper; Stx, Hhx og Htx. Også dette studie tager udgangspunkt i en kulturel tilgang og analyserer skolekulturer på basis af Edgar Scheins (1989) kulturteori (Wiedemann 2002). Peter Henrik Raaes afhandlingsarbejde, Troeghedens rationalitet, tematiserer omverdenens forandringspres på gymnasiet i 2003 fra en modernitetsteoretisk vinkel (Raae 2005). Derudover betragtes skolen i afhandlingen fra et organisationspsykologisk perspektiv som et mentalt organisationsrum, og det analyseres, hvordan organisatorisk træghed sættes på gymnasiets dagsorden i forandringssammenhæng (Raae 2005, 7). Den sidstnævnte psykodynamiske indfaldsvinkel, som tager afsæt i Tavistock-traditionen, er desuden en ofte anvendt tilgang i organisationsanalyser af gymnasiets forandringsprocesser. Denne teoretiske tilgang er centreret omkring samspil mellem individ, arbejdsliv og samfund, som forstås som inter-subjektive og intra-subjektive processer under påvirkning af det ubevidste ${ }^{2}$. Blandt andet vælger Åse Lading dette afsæt for en analyse af gymnasielæreres strategier i grupper, beskrevet i Ph.d.-afhandlingen Vi er jo kolleger, ikke konkurrenter... (Lading 2005).

Ovennævnte studier har bidraget med værdifuld indsigt i lederroller og arbejdsopgaver i gymnasiet. Det er imidlertid kun få videnskabelige bidrag, som udforsker ledelsesarbejdet i skolen med fokus på de relationelle ledelsesprocessers håndtering. I en dansk kontekst kan det nævnes, at Marie Ryberg og Dorthe Pedersen samt Dorthe Pedersen og Camilla Sløk har bidraget med et centralt opfølgende undersøgelsesarbejde på reformens udvikling på skolerne (Pedersen \& Ryberg 2012; 2013; Pedersen \& Sløk 2014). Fokus er her på studier af ledelse og 
organisering i det ny studieretningsgymnasium, men undersøgelsesarbejdet er ikke specifikt rettet mod samspillets mikroprocesser. I denne artikel bidrager vi imidlertid med analyser af mikroprocesserne i forandringstiltagenes tilblivelsespraksis. Det er herfra muligt at tilbyde nye tematiseringer af ledelsesdynamikkerne og disses forankring i primus inter pares-ledelsen.

\section{Professionelles autonomi i klassisk og nyere litteratur}

I det følgende afsnit gennemgås centrale ideer om professionelle, som de præsenteres i klassisk sociologi såvel som i nutidig, kritisk litteratur. Afsnittet danner baggrund for artiklens empiriske analyse.

Inden for sociologien hersker der på ingen måde konsensus om, hvordan en profession defineres, ligesom der heller ikke er konsensus om, hvilke grupper der henregnes under en profession (Alvesson 2004). Ser man på litteraturen, ser det dog ud til, at spørgsmålet om autonomi har været centralt og betragtes som et af de vigtigste karakteristika, når der skelnes mellem professionelle og andre erhvervsmæssige grupper (Kragh Jespersen 2005; 2012). Det antages at være et karakteristika ved professionsudøvelsen, at de professionelle har omfattende beføjelser til at foretage skøn i komplekse arbejdssituationer. På baggrund af arbejdets kompleksitet forventes de professionelle ikke at være forpligtede på at følge fastlagte regler og procedurer; men må udøve deres ekspertise i forhold til konkrete situationer (Collins \& Evans 2007). Autonomien ses som værende understøttet af den ekspertviden, som de professionelle opnår gennem deres specialiserede uddannelse (Ibid.). Forvaltningen af den autonome rolle er et ofte gentaget tema i nyere organisationsteori og i studier af professionelle
(Adler m.fl. 2008; Kragh Jespersen 2012; Noordegraaf 2006; 2007; 2012)

Nyere studier peger imidlertid også på, at forståelsen af, hvad der udgør den professionelle rolle, er under forandring - herunder i forbindelse med væksten i de såkaldte semi-professioner (Hjort 2004) ${ }^{3}$. Mirko Noordegraaf (2007) argumenterer for, at der med fremskridtene i videnssamfundets neoliberale ledelsesmæssige kontrol og forbrugerkontrol er sket en svækkelse af de professionelles autonomi. Dette sker samtidig med, at de klassiske professioner i vid udstrækning udfordres gennem opkomsten af en lang række semi-professioner på velfærdsområdet (sygeplejersker, lærere, pædagoger, m.fl.). I skolerne forekommer f.eks. nu en ny form for bureaukrati med NPM-tiltagene, som er karakteriseret ved en regulering og regelstyring af de professionelles arbejde. Nye former for værktøj er introduceret, såsom medarbejderanerkendelsessystemer, evalueringer og feedback-systemer, der skal være med til at højne kvaliteten i arbejdet. De nye former for professionalisme involverer diskussion og dialog i den enkelte organisation - krav om forhandlinger, som alt sammen er med til at udfordre den professionelles autonomi. Fra en governmentalitets-vinkel har Lars Thorup Larsen (2013) påvist, hvordan professionelles autonomi svækkes under indflydelse af NPM-tiltag, idet professionelle i vid udstrækning bliver gjort til agenter for politiske strategier på en række policy-områder. På denne måde rammesættes og påvirkes det centrale spørgsmål om professionelles autonomi og deres indbyrdes relationer på ny, og nye samarbejdsformer mellem ledere og f.eks. lærere opstår. På den ene side udfordrer udviklingen den traditionelle professionelle autonomi, mens den på den anden side giver de professionelle nye muligheder for at opnå indflydelse på de regulerende værktøjer samt de standarder, der sættes på orga- 
nisatorisk plan. Nogle forskere (Brint 1994; Noordegraaf 2007) argumenterer endda for, at autonomi ikke længere er af betydning, idet ingen professionel kan gøre krav på autonomi i konfrontationen med de nutidige forandringer og reguleringen af det professionelle arbejde. Noordegraaf foreslår $i$ forlængelse heraf en ny ramme for forståelsen af professionalisme i videnssamfundet. Han introducerer begrebet hybridiseret professionalisme som koncept for forståelsen af professionelle i flertydige domæner. Begrebet henviser til den særlige udfordring, som især ledere i offentlige organisationer står overfor. I offentlig ledelse, hvor ledelsen ofte har samme faglige bagrund som deres ansatte, står lederne overfor at skulle varetage opgaver, der dels knytter sig til professionel ledelse (personaleledelse, forandringsledelse og strategisk ledelse), dels til faglig ledelse og driftsledelse (Noordegraaf 2007, 781). I tråd med forståelsen af professionelle i flertydige domæner udfolder Mats Alvesson (2004) konceptet om flertydighed. Han argumenterer for, at organisationer og arbejdsliv, især inden for det han definerer som 'videns-intensivt arbejde', udgøres af udpræget flertydige fænomener. Alvesson påpeger, at det er nødvendigt at anerkende denne flertydighed i forskningen. Forskeren må være villig til at undersøge den usikkerhed, der præger aktørers aktiviteter i organisationerne, hvis han vil opnå en forståelse af de professionelle arbejdsprocesser (Alvesson 2004, 48). Man kan tilføje til Alvessons udsagn, at forandringsprocesserne i organisationerne vil intensivere de flertydige situationer. Nye forståelser og nye praksisser i organisationerne vil føre til en intensivering af usikkerheden og flertydigheden. Dermed ser det ud til, at Alvessons position og koncept om flertydighed har en særlig relevans for forståelsen af professionelles arbejdsliv under ledelsesmæssig forandring.
Med udgangspunkt i det flertydige appliceres i denne artikel en etnografisk tilgang og et paradokskoncept til datamaterialet. Såvel den etnografiske tilgang som den anvendte paradoksforståelse udfoldes nærmere i artiklens efterfølgende metodiske afsnit. Med et empirisk afsæt undersøges ledelsesprocesserne efterfølgende i gymnasiet under forandring i praksis.

\section{Processer i praksis}

\section{Etnografisk tilgang}

Datamaterialet i artiklens undersøgelse er genereret fra to mellemstore gymnasieskoler med hver 400-500 elever og omkring 5060 lærere. Materialet inkluderer to surveys, observationer af læreres og lederes interaktioner og 40 dybdeinterviews med ledere og lærere, såvel som analyse af skrevne fortællinger, der omhandler reformerfaringer og er produceret af deltagerne. Datamaterialet er blevet indsamlet longitudinalt, det vil sige fra den første reformforberedende fase i efteråret 2004 til slutningen af det første skoleår med implementeringen af reformen i 2006. Igennem dette tidsrum fulgtes de responsive processer mellem ledelse og medarbejdere, guidet af spørgsmål som: 'Hvad var ledelsens strategier for ledelse til at begynde med?', 'Hvordan reagerede loererne?', 'Og hvordan evalueredes processerne efter et år, både af ledelse og af loerere?', 'Hvordan blev reformens idéer oversat i forandringsprocesserne i praksis?'

I forfølgelsen af svarerne på disse spørgsmål var observationer og interviews de vigtigste tilgange til undersøgelsesarbejdet med henblik på at udfolde et detaljeret etnografisk studie af mikroprocesserne på skolerne (Juel Jacobsen 2014). Observationerne har fra start været relativt ustrukturerede og koncentreret omkring ledelsesudøvelse og medarbejderreaktioner herpå og 
knyttet til iværksættelsen af reformforandringer i gymnasiet. Data er blevet kodet og testet gennem yderligere observation og interviews. Gradvist er der opnået en højere grad af strukturering i både observationer og interviews, indtil der til sidst er udviklet nye begreber og teori til ny indsigt. Det er på baggrund heraf, at det har været muligt formulere de emergerende paradokser i praksis i organisationen i relation til de organisatoriske forandringsprocesser. Vores udgangspunkt har været, at vi, i så vidt omfang som muligt, har ønsket at give empiriproduktionen vægt - frem for at fastlægge en overordnet teoretisk rammeforståelse for vores analyse. Dette gør imidlertid ikke vores empiriproduktion teorifri. Vores videnskabsteoretiske ståsted fremskriver et relationelt, processuelt og aktivitetscentreret perspektiv på organisatorisk forandring og handling (Helin et al. 2014). Vi har i særdeleshed været optaget af at undersøge brud, usamtidigheder, mangetydigheder og paradokser i det empiriske materiale ${ }^{4}$.

\section{Paradokser}

Med henblik på at fortolke interaktionsprocesserne valgte vi at benytte os af et paradoksbegreb for at forstå samspillet mellem ledelse og professionelle i flertydige arbejdssituationer. Vi har valgt at anvende Robert Quinn og Kim Camerons (1988) definition af paradokser, som er hyppigt brugt som et udgangspunkt for undersøgelser af paradokser i organisationer (Lewis 2000; Stacey 2003; Smith \& Lewis 2011). Quinn og Cameron ser paradokser som værende: The simultaneous presence of contradictory, even mutually exclusive elements (1988, 2). Quinn og Cameron specificerer endvidere, at paradokser omfatter elementer, der er både modsatrettede og forbundne - elementer, der isoleret set synes logiske, men som virker irrationelle, når de skal fungere samtidigt. I paradokslitteraturen fremhæ- ves det som regel, at denne måde at se paradokser som dikotomier kan give ophav til forsimplet enten-eller-tænkning og fordrer et valg mellem polerne i paradokset (Stacey 2003; Lewis 2000; Smith \& Lewis 2011). Et alternativ til den bipolære tilgang er, ifølge Wendy Smith og Marianne Lewis (2011), at se paradokser som indeholdende konkurrerende krav, der skal håndteres samtidigt. Det vil sige, at i stedet for at vælge mellem den ene eller anden, bør der tages vare på begge poler. Denne måde at tænke på har en dual både-og-struktur (Stacey 2003, 11; Smith \& Lewis 2011). Den bipolære såvel som den duale tilgang bærer dog stadig en forestilling om elimination af modsætninger. Samtidig har de nævnte tilgange et præskriptivt sigte for den organisatoriske ledelse (Smith \& Lewis 2011, 386). Til analysen af gymnasiets ledelsesprocesser har vi imidlertid søgt et teoretisk skifte, som fokuserer opmærksomheden på en forståelse af de relationelle dynamikker i organisationerne. Vi anvender derfor begrebet som en empirisk analytisk linse, som gør det muligt at se paradokser som en potentiel effekt af flertydigheden. Vi har dermed valgt en analysestrategi, hvor vi har arbejdet for at se komplekse dynamikker i organisationen, og har med et empirisk afsæt som forskere skabt et udgangspunkt for at forstå, hvad spændingerne består af, og hvordan spændingerne kommer i spil i organisationerne. Dette er også baggrunden for, at artiklen ikke lægger et teoretisk afgrænset ledelsesbegreb til grund for undersøgelserne. Analysestrategien kan opsummeres i tre trin. I det første trin var det centralt at fastholde rigdom og detaljer i de komplekse etnografiske data på materialets egne præmisser. Denne tilgang til materialet kan karakteriseres som fænomenologisk og hermeneutisk og tog udgangspunkt i Interpretative Phenomenological Analysis (IPA), som beskrevet af Jonathan Smith \& 
Mike Osborne (2003). Denne fænomenologiske tilgang blev anvendt, fordi den bidrog til at udsondre empiriske tematiseringer af læsningen. I det andet trin af analysen var der fokus på spændinger og modsætninger i aktørernes interaktioner. Målet med dette var at specificere paradokserne i de relationelle ledelsesprocesser. Trin tre i analysen udgjorde en sammenfatning af paradokstemaer og i tilknytning hertil et uddybende fokus på håndteringen af balancerne i paradokserne. Fra denne indgangsvinkel har vi set interaktionsmønstre, som er irregulære, ustabile, uforudsigelige og konstrueret lokalt af aktørerne i praksis. Analysestrategien er herved ikke foreskrivende eller normativ, snarere deskriptiv. Vi betegner i artiklen paradokserne som organisatoriske, når de opstår i relationen mellem ledelse og medarbejdere og har konsekvenser for de organisatoriske arbejdsprocesser. Metoden har således til formål at udgrunde, hvordan ledelse konkret bliver meningstilskrevet og gjort i situerede kontekster.

I de følgende afsnit udfoldes resultater af undersøgelsesarbejdet. Artiklen fremlægger de implikationer, som reformkravene får for måder at lede arbejdet på i skolerne, som er præget af primus inter pares-ledelse. Efter en kort introduktion til organisation og ledelse på case-skolerne præsenteres paradoksmønstre relateret til konstruktionen af forandringerne for hver af de to skoler, henholdsvis HTX og STX. De udvalgte temaer som præsenteres er mønstre, som konstituerer dynamikkerne mellem de deltagende aktører i forandringsprocesserne.

I første del af hvert skoleafsnit er der fokus på ledelsens refleksioner over, hvordan professionerne bedst håndteres i relation til implementering af reformen. Efterfølgende præsenteres lærernes reaktioner på ledelsens tiltag såvel som deres reaktioner på centrale reformkravs udmøntning i praksis.

\section{Reform, professionelle og paradokser i praksis}

\section{HTX og STX}

For case-skolen STX gælder det, at den på undersøgelsestidspunktet er statsligt forankret og bygningsmæssigt en selvstændig organisation, hvorimod HTX i det daglige er forankret i en større organisatorisk sammenhæng på en teknisk skole. HTX er altså en afdeling med egne uddannelsesmæssige karakteristika, men på samme tid indlejret i den større organisations ledelse, værdisæt og økonomiske ansvar. De to case-skoler er på dette punkt organisatorisk forskellige, men ens med hensyn til det faktum, at den daglige ledelse er det primære ansvarsområde for én person, der assisteres af tre mellemledere. Ledelsen på begge skoler er rekrutteret efter primus inter pares-princippet (Greenleaf 2003). Både leder og mellemledere på HTX har tidligere været lærere på skolen. På STX har lederen været lærer på en lignende skole, og det samme gælder mellemlederne. De to skolers beslutningstagningsprocesser er organiseret efter forskellige mønstre. På STX er kompetencen til at træffe beslutninger uddelegeret i en særlig udvalgsstruktur. Udvalgene arbejder efter en konsensustænkning. De diskuterer kort sagt, indtil de er enige. På HTX tages beslutninger kollektivt $\mathrm{i}$ et Pædagogiske Råd efter præsentationer fra forskellige arbejdsgrupper. Selvom STX og HTX tilsyneladende er signifikant forskellige med hensyn til deres organisatoriske tilhørsforhold, deler de to skoler mere eller mindre primus inter pares-rekruttering af ledelsen samt idealer om en meget flad beslutningsstruktur. I de følgende afsnit præsenteres de empiriske mikroprocesser, som er knyttet til implementeringen af reformforandringer i gymnasierne. 


\section{HTX: Mellem ledelse ad bagdøren og synlig ledelse}

Synlighed og supervision er nøgleord for den nye relation mellem ledelse og medarbejdere ifølge gymnasiereformen. Ledelsen skal bidrage i den enkelte skoles helhedstænkning med synliggjorte mål og rammer for indsatsen. På HTX udtrykker uddannelseslederen som udgangspunkt i den reformforberedende fase sit grundlæggende syn på ledelse med reference til lærernes baggrund som 'akademikere' og 'professionelle':

"Altså i gymnasieverdenen, hvor de fleste er akademikere, bryder de sig ikke meget om, at der er nogen, der beslutter ret meget for dem... Man må gerne gå og råbe og skrige lidt af dem uden at have nogen ledelse, men hvis de ser det som ledelse, bliver 'man' [loererne] fornoermede, fordi 'vi ved godt selv, hvordan det skal voere'".

Ledelsen tager med andre ord udgangspunkt i, at medarbejderne er ledelsesfremmede, som beskrevet i traditionel professionsforståelse. Med dette som et grundlæggende vilkår for ledelse er der meget lidt rum til åben og synlig ledelse på skolen. Set i relation til skildringen af den autonome professionsforståelse, som beskriver professionelle som ledelsesfremmede, kan det være en kompliceret opgave at skulle matche signalerne, som er givet for forandringerne på gymnasiet. I forlængelse heraf ser det ud til, at flad struktur og lighed bliver essentielle mål for ledelsen. En konsekvens af denne tilgang til ledelse, i relation til de nye idealer om synlig ledelse, er, at den praktiseres sporadisk og udfoldes sammen med en idé om, at ledelse skal 'luskes ind'. I forbindelse med implementeringen af et nyt evalueringssystem siger uddannelseslederen bl.a.:
"Man kan godt sige, at nogle af de idéer, vi har om de her ting [i reformen], dem lusker vi jo så ind, når vi nu taler med folk om de forskellige ting, der skal ske. Altså, vi har ikke trynet noget den vej rundt."

De ledelsesmæssige initiativer er hermed halvt skjulte. Men eftersom ledelse er nødvendig, bliver det nogle gange lusket igennem. Ledelsen omtaler desuden selv lejlighedsvist egen ledelse som 'ledelse ad bagdøren'. En lærer beskriver skolens ledelse med begrebet 'flydende ledelse' og forklarer:

"Det er ikke saerlig synligt, hvad der foregår (...) Og det er proecist der, vi har det store problem."

En mellemleder giver udtryk for, hvad der i hendes optik kendetegner 'anstændig ledelse':

"... Selvfølgelig ville det voere muligt, men det ville ikke voere anstoendigt, hvis en leder ikke også er loerer. Jeg mener... Jeg synes, vi alle sammen skal undervise."

Det er altså et ledelsesmæssigt udgangspunkt, at ledelse bliver meget mere acceptabel for både ledere og medarbejdere, når lederne stadig er lærere - og dermed i et lige forhold til deres medarbejderstab. Det vil sige med fælles fagligt udgangspunkt. Med henblik på at skabe ledelse af de konkrete forandringer i reformen, som matcher lighedsidealet på HTX, vælger den formelle ledelse at sikre sig, at ildsjæle blandt medarbejderne i organisationen kan blive det mellemled, som kan drive forandringsarbejdet. Den formelle ledelse udpeger et ledelseslag af medarbejdere, der ofte agerer som ildsjæle på skolen. Medarbejderne udpeges til at træde i karakter som ildsjæle og drivkraft i forandringsprocessen med "pen 
og pisk", som det formuleres af uddannelseschefen. Således forbliver frontfigurerne i forandringsprocessen kolleger og lærernes ligemænd. Primus inter pares-aspektet og besiddelse af den specialiserede faglige ekspertviden er på denne måde konstituerende for ledelsesforståelsen, selv om det giver hovedbrud og er anledning til skæve organisatoriske initiativer, når reformen skal omsættes i praksis. Ideerne om kollegialt fællesskab afspejler sig desuden i ledelsens måde at omtale ledelse på. Medarbejdere omtales konsekvent som kollegaer, og ledelse beskrives i biologiske metaforer - grupper 'udkrystalliserer sig', 'spirer', 'bliver til', 'vokser naturligt frem' og er 'dynamiske'. På denne måde naturaliseres processerne. Udøvelse af synlig ledelse, uden at blive genkendt som ledere af lærerne, fører gennemgående til paradoksale praksisser, som gennemsyrer skolens dagligdag. Daglig ledelse af reformen på HTX er med andre ord fuld af omveje med henblik på at lede via ikke-ledelse.

\section{Responsive processer: 'samarbejdet har været meget bedre - men ikke nemmere'}

Blandt lærerne på HTX er det et gennemgående tema fra starten af reformimplementeringen, at det tværfaglige samarbejde og teamsamarbejdet, som reformen foreskriver, betragtes som den største udfordring. Samtidig er der dog ingen tvivl hos de involverede om, at intentionerne med samarbejdet er gode og ønskværdige. Dette synspunkt står ved magt og gentages efter det første år med reformen. En lærer siger bl.a.:

"Det er rigtigt godt at lave samarbejdsprojekter. Vi bliver tvunget ind i nogle forbindelser, som vi nok ikke selv havde valgt; men det er meget motiverende, og man kan moerke, at de studerende også bliver motiverede. Sam- arbejdet har voeret meget bedre; men ikke nemmere."

De nye samarbejdsprocesser lever op til lærernes forventninger langt hen ad vejen. Men de rummer også uventede udfordringer, som skal håndteres undervejs. Den flydende ledelse viser sig i denne sammenhæng at indebære, at ledelsen ikke nødvendigvis reagerer, når medarbejderne efterspørger ledelse. I forbindelse med en konkret konflikt, der involverede et tværfagligt samarbejde på HTX, anmodede lærerne om ledelsens indgriben i processerne. Et medlem af en gruppe samfundsfagslærere indgav en skriftlig klage på vegne af sin gruppe. I klagen fastslog han, at de nye grundkurser for eleverne var blevet udviklet på en måde, som gav anledning til stor utilfredshed. Teknologilærerne ville ikke samarbejde, og der var problemer med at skabe tværfagligheden. Det giver "murren", som læreren udtrykte det, og det førte til et teknologiforløb, hvor alle andre fag er blevet "påhoengsfag". Det viser sig imidlertid, at der er tale om en samarbejdsudfordring, som længe har været tematiseret, men som er blevet forstærket af det forpligtende reformkrav om samspil. Med samarbejdskravet synliggøres altså også et ledelsesbehov for støtte i de vanskelige nye samarbejdsprocesser. Dette behov bliver dog ikke indfriet, da ledelsen aldrig svarer på klagen. Ifølge medlemmet af gruppen af samfundsfagslærere fører dette fravær af ledelse til formationen af uofficielle og meget ubehagelige magtkonstellationer lærerne imellem:

"(...) Vi fär de her uofficielle magtkonstellationer - stoerke loerere, svage loerere. Hvem er god til at holde de andre nede? (...) Det kan ikke voere rigtigt, at vi skal skoendes med kolleger og rette på hinanden." 
På denne måde opstår der et organisatorisk paradoks i relationen mellem ledelse og medarbejdere, som har konsekvenser for forandringsarbejdet. Ledelsen afholder sig fra at lede på baggrund af antagelser om, at lærernes autonomi skal beskyttes, alt imens lærerne efterspørger mere ledelse til vanskelige dele af forandringsprocesserne. Der opstår i denne situation et organisatorisk deadlock, som her kunne benævnes som et primus inter pares-deadlock, dvs. en situation, hvor hver part i sammenhængen reagerer på den anden part på en måde, så et gensidigt, men for begge parter utilfredsstillende interaktionsmønster, vedligeholdes (Spencer \& Dale 1979, 679).

Reformens obligatoriske krav om, at lærere skal forandres fra at se sig selv som individuelle gymnasielærere til at se sig selv som medarbejdere i en organisation, er en blandet oplevelse for lærerne på HTX. Som det illustreres i det foregående afsnit har reformen levet op til de positive forventninger på nogle områder. Efter det første reformår er der dog også bekymringer omkring teamsamarbejdet. Et omfattende administrativt ansvar er blevet lagt over på teamstrukturen. I løbet af det første år med reformen opleves de ekstra opgaver som tidskrævende og problemskabende på daglig basis. En lærer beretter, hvordan det aspekt af reformen, der bekymrer ham mest, er "den gigantiske registrering af alting", især studieplaner, både de intenderede og de realiserede: "Det er virkelig det alle taler om, det alle hader, og som noesten ingen kan se meningen med...". Dermed bliver det deskriptive arbejde, som er introduceret af reformen for at skabe sammenhæng i organisationen og i sidste ende bedre undervisning gennem samarbejde, oplevet af lærerne som noget, der tager opmærksomheden fra undervisningsopgaven på grund af det administrative overload. Situationer som disse gør, at medarbejderne også i denne sammenhæng søger mere ledelse, og der opstår et behov for understøttelse af teamarbejdet. Et interview med rektor omkring udfordringerne ved teamsamarbejdet gør det imidlertid klart, at strategien for den daglige praksis i organisationen er, at den fortsat skal være så flad som muligt, som han udtrykker det. Det betyder, at teamets funktioner og fordeling af ansvar ikke vil blive beskrevet yderligere. Strukturer for teamarbejde er fraværende, og et flydende ansvar bliver kontinuerligt debatteret $\mathrm{i}$ teamene og forbruger store mængder af ressourcer i organisationen.

\section{STX: Ledelse mellem diskret kontrol og synlig ledelse}

På STX underviser alle ledere med udgangspunkt i en antagelse om, at afstanden mellem leder og lærer ikke må blive for stor. Der er ingen tvivl hos ledelsen om, at det skal være sådan. Det betragtes som vigtigt at "holde fingrene $i$ jorden", som en leder udtrykker det, og forblive forbundet med lærergerningen. Skolens rektor fortæller desuden om ledelsens grundlæggende tanker og giver herved indsigt i, hvorfor ledelsen søger at udjævne forskellene mellem ledelse og lærere:

\section{"Gymnasieverdenen er meget ledelsesfrem- med - ikke fremmed, men ledelsesfjern. Vi [loererne]vil helst have så lidt udefrakom- mende ledelse på os som muligt. Udefrakom- mende - det er mig! Udefra, det er alt andet end loereren selv. Det er sådan den her dob- belthed, der er omkring ledelse, som er van- skelig at have med at gøre."}

Dobbeltheden, som italesættes ovenstående, refererer netop til det krydspres, som opleves ved at skulle navigere mellem reformens krav om ny professionalisme i form af synlig ledelse overfor det at skulle håndtere nærheden til medarbejderne i form af fæl- 
les fagligt afsæt. I praksis udmønter det sig på STX i, at lederne er enige om, at deres arbejde først og fremmest består i ledelse gennem kommunikation. En af skolens ledere beskriver det på følgende måde:

"For mig er ledelse dialog, og så er det dialog, og så er det dialog. Jeg har sådan nogen mere eller mindre løse idéer om vaerdibaseret ledelse, at det er i samtalen og i fastloeggelsen af foelles voerdier, at man når målene. Det er sådan min overordnede idé som leder. Jeg er ikke typen, der udsteder ordrer på noget tidspunkt. (...) Som leder skal man voere $i$ besiddelse af en høj grad af empati, og man skal kunne leve sig ind $i$, hvad der foregår $i$ de enkelte teams. Man skal have gode kommunikative kompetencer, og man skal have en høj grad af fleksibilitet."

Den samme leder giver udtryk for, at medarbejderne skal skubbes, men uden at føle sig styret eller begrænset af ledelse. Ledelse er:

\section{"(...) Altså den der fingerspidsfornemmelse af, hvor griber man ind som administrator, hvor griber man ind og hjoelper og vejleder, uden at det føles, som om man kommer ind for at styre, men at man faktisk er der for at skubbe processen videre. (...) Og det er no- get af det, jeg mener, bliver det rigtigt store arbejde."}

På spørgsmålet om, hvordan det med en meget vid selvstændighedsmargen er muligt for ledelsen at følge op på arbejdet, svarer han, at det gør man selvfølgelig ved at spørge. Lærerne kan ikke overvåges; tværtimod er tillid helt centralt. På samme tid er der dog behov for en grad af kontrol, men så kan den udføres diskret:

"Vi følger op på, om de formelle ting er blevet lavet. Hvordan ser det ud i uddannelsespla- nen? Er de ting kommet på hjemmesiden, som skal på hjemmesiden? Det kan man jo gøre ganske diskret."

På HTX implementeres ledelse via bagdøren; på STX følger ledelsen op på reforminitiativerne, men diskret og usynligt. Idealet om, at ledelsen bør holde lav profil og lægge vægt på lighed i relationen til medarbejderne og samtidig leve op til kravene om mere synlig ledelse, er herved også et betydningsfuldt paradoks på STX, et paradoks, som leder til andre relaterede paradokser i organisationen. Også her er der parallelitet med dynamikkerne på HTX.

\section{Responsive processer: 'samarbejdet er positivt og irriterende svært'}

Efter den første periode med implementering af det tværfaglige samarbejde i praksis blev lærerne spurgt om deres oplevelser af samarbejdet. Interviewene afspejlede en dominerende tendens. De nye muligheder for at arbejde med kolleger blev betragtet som et af de bedste aspekter af reformen, uden at samarbejdet dog på nogen måde var problemfrit. En lærer opsummerer oplevelserne således: "det er positivt og irriterende svoert". En nærmere undersøgelse af de positive aspekter viste, at samarbejdet oplevedes som forbundet med en social dimension og i tilknytning hertil en støttende kollegialitet og en faglig udveksling, der kunne erstatte tidligere tiders konkurrerende kollegarelationer. En lærer forklarer:

"Jamen, jeg synes det har vaeret utrolig givende, at vi som loerere kan sidde og få de faglige input, og at vi nu føler, at vi ikke bare sidder og forbereder den enkelte time derhjemme (...) Vi udvikler vores faglige forståelse $i$ foellesskab, $i$ stedet for vi sidder og bare engang imellem kan have et møde og snakke og gøres os til af, hvor meget klogere vi er end hinanden." 
Tidligere tiders individuelle lærer har været koncentreret om at demonstrere stor faglig identitet, også overfor kollegaer, men det er ikke ensbetydende med, at behov for udveksling og sparring i det daglige ikke samtidig har været til stede. Tværtimod ser det ud til, at behovet for professionel sparring kort sagt legaliseres af reformens krav om tværfaglighed. I diskussionen om dannelsen af grupperne til det tværfaglige samarbejde bliver det imidlertid også tydeligt, at der har været meget forskellige måder at tackle denne proces på. En stor del anarki og ubehag har præget processen. En lærer forklarer:

\section{"(...) Men der vil altid voere nogen, der er udenfor grupperne, man kan ikke bare melde sig ind, ud over at vi har vores team om klas- sen, så vil der altid opstå en roekke teams indenfor klassens loerere, der arbejder godt sammen. De vil hurtigt finde ud af, hvad et forløb skal handle om, og så er der andre, der bare ikke kan komme med i det."}

De tværfaglige arbejdsprocesser har i meget høj grad været overladt til lærernes selvorganisering, og lærerne beretter efterfølgende om, at processen bød på manglende koordinering og forflyttelse af ansvaret fra den ene til den anden. At det gik godt i sidste ende var baseret på tilfældigt opståede alliancer. Allerede i reformforberedelsesfasen formuleres det af en lærer, at ledelsen nok mangler ledelsesredskaber til at gribe ind $\mathrm{i}$ forbindelse med samarbejdets tilrettelæggelse, dér hvor der er problemer. At der mangler ledelsesredskaber er en mulig tolkning af den fraværende ledelse. Det er dog også muligt, at ledelsen netop holder sig fra at sætte rammer om arbejdet af frygt for at komme til at optræde kontrollerende i det, de kalder 'selvstændighedskulturen'. Det står imidlertid klart, at lærerne undrer sig over den fraværende ledelse, og i sidste ende, på STX, er vrede over det, som beskrives som ledelsens fejltolkning af medarbejdernes behov. Set fra en læreroptik er det en fejltolkning af behovet for lederindsats, når ledelsen håndterer problemerne ved at invitere en ekstern oplægsholder, 'som holder et fløjt om ledelse, teams og omstillingsparathed og sådan noget'. Som det udtrykkes af en lærer; i reformpraksisfasen er det en hån, når nu det er "lyttende ledelse og hioelp til strukturering af samarbejdet, der er brug for."

Ledelsen træder altså til side af respekt for det behov, man antager, lærerne har for selvbestemmelse. Resultatet er på STX, at manglen på ledelse i reguleringen af samarbejdet opleves som et ledelsesvakuum, hvori kriser opstår. Dette resulterer endvidere $i$, at medarbejderne føler vrede og frustration, fordi de ikke føler, at deres behov bliver mødt af ledelsens initiativer. Kort sagt, ledelsen afstår fra at lede, mens medarbejderne efterspørger mere ledelse. Denne paradoksale situation fører til et intensiveret polariseret interaktionsmønster og dynamikker, der understøtter tilblivelsen af bipolære meninger på denne skole.

\section{Konklusion: paradokser, deadlocks og omveje i ledelsesarbejdet}

Dette afsnit opsummerer NPM-forandringerne med fokus på paradoksale dynamikker i skolernes mikroprocesser. På både HTX og STX synes primus inter pares-ledelsen at være det dominerende ledelsesafsæt. Dette har store implikationer for forandringsprocesserne i organisationerne. Næsten identiske paradokser opstår på de to skoler med ensartede dynamikker til følge, men dog med lokale variationer. Baseret på den empiriske analyse af reformforandringerne ser vi, at i skolekonteksten sætter reformkravene ledelsens primus inter pares-afsæt i spil 
med implikationer for derpå følgende paradokser i de to skoler:

- mellem ledelsens synlighed og lighedsbestræbelser

- mellem synlig ledelseskontrol og lærerautonomi

- mellem synlig ledelse og selvledelse i teams

- mellem synlig ledelse og flad beslutningsstruktur

- mellem synlig ledelse og uigennemsigtig kommunikation.

Antagelsen om, at de, lærerne, ser sig selv som autonome - og dermed er ledelsesfremmede - får ledelsen til at gå langt for at lede, men samtidig sikre en flad struktur og lighed og i samme tråd en ikke alt for synlig ledelse. Ledelse sniges ind eller udføres diskret, selvom reformen peger mod synlig ledelse. Det første og grundlæggende paradoks opstår her mellem ledelsens synlighed og lighedsbestræbelser. Et paradoks, som er udtryk for ledelsens navigation i et krydspres mellem traditionel faglig ledelse og den ny professionelle ledelse. Det andet paradoks afspejles i ledelsens anstrengelser for at følge op på lærernes reformarbejde, det vil sige, at ledelsen kontrollerer usynligt. Ledelsen ser kontrolundgåelse og maksimal frihed som centrale ledelsesstrategier, idet de antager en stærk selvstændighedskultur. Reguleringen uden kontrol finder sted med stor vægt på den idé, der formuleres af rektor på STX under reformens forberedelsesfase:

"Poedagogisk ledelse kroever, at man giver den bevoegelsesfrihed, der er brug for, for at laererne kan udvikle sig på en naturlig og afslappet måde."

På begge skoler har der imidlertid været et udtrykt ønske om mere ledelsesstøtte i de processer, der involverer nye svære samarbejdsformer. I forlængelse af reformens udfordrende krav til samarbejdsprocesser opstår der et tredje paradoks: et paradoks om synlig ledelse og selvledelse $i$ teams. Det er meningen, at den individuelle lærer skal indgå i forpligtende samarbejde forankret i teams med henblik på at udforme tværfagligt samarbejde. Lærerne er generelt meget positive overfor forandringerne, men de udtrykker behov for ledelse til at støtte og facilitere forandringsprocesserne og til endda engang imellem at gribe ind i konfliktsituationer. Således opstår dette paradoks, når ledelsen undgår at lede i respekt for lærernes autonomi i samarbejdsprocesserne. Reguleringen af de nye samarbejdsprocesser placeres mellem justeringer, som er foretaget af medarbejderne og justeringer foretaget af ledelsen. Ifølge lærerne opstår der et ledelsesvakuum, når processerne ikke guides. På begge skoler ser situationen ud til at give anledning til utilfredsstillende interaktionsmønstre for begge parter. På STX fører det til stærke bipolære spændinger efter det første skoleår med reformen. På HTX bliver de endda til deadlocks i de organisatoriske processer. Ikke desto mindre skal det understreges, at samarbejdet, som foreskrives af den nye reform, stadig evalueres positivt af lærerne. På baggrund af de empiriske data og analyser, som præsenteres i denne artikel, illustrerer interaktionsmønstrene, at de traditionelle autonome læreres praksis har undergået en forandring. Et fjerde paradoks mellem synlig ledelse og flad beslutningsstruktur opstår under reformprocesserne på begge skoler. På STX bliver ledelse mere acceptabel, både for lærerne og ledelsen selv, fordi ledelsen også består af tidligere lærere. Dette er også tilfældet på HTX, hvor vi hører, hvad 'anstændig ledelse' er, set fra ledelsessynspunkt. Som en leder siger, "det ville ikke voere anstoendig ledelse, hvis vi ikke også var loerere". Denne opfattelse af ledelse 
ser vi også på STX. For at være i stand til at skabe ledelse, der matcher idealerne om lighed på HTX, ud af de konkrete forandringer, reformen bringer med sig, ses det som den formelle ledelses hovedopgave at sikre sig, at ildsjælene blandt lærerne bliver den drivende kraft $\mathrm{i}$ forandringsprocesserne. Baseret på denne forståelse udvælger den formelle ledelse et mellemlag af lærere, der skal tage ansvar for at drive forandringsprocesserne fremad "med pen og pisk", som det formuleres af rektor. Når ledelsen ikke må være synlig, bliver indirekte kommunikation et centralt element i ledelsesarbejdet. I kommunikationen afspejles tvetydige og uigennemsigtige dynamikker. I den forbindelse opstår et femte paradoks på skolerne, nemlig et paradoks mellem synlig ledelse og uigennemsigtig kommunikation. På STX er der enighed i ledelsen om, at arbejdet med at lede de krævende forandringsprocesser bedst gøres ved hjælp af velvalgte kommunikationsstrategier. Dette afspejler sig også på HTX, jævnfør ledelsens omtale af ledelse i biologiske metaforer. Det metaforiske sprog fungerer som en slags black box, der giver ledelsen mulighed for at lede uden at være alt for synlig. 'Flydende ledelse' er det mest beskrivende begreb for den form for ledelse, der praktiseres på HTX, hvor man benytter meget kreative omveje til ledelse gennem ikke-ledelse.

\section{Gensyn med en etnografisk tilgang og paradokskonceptet}

Efter opsummeringen af de paradoksale dynamikker på de to skoler vil vi kort vende tilbage til den etnografiske tilgang og paradoksbegrebet, der benyttes i udforskningen af de professionelles mikroprocesser i artiklen. Formålet med artiklen har været at undersøge forandringerne i et relationelt og dynamisk perspektiv. Vi bruger Quinn og Camerons definition som udgangspunkt for vores forståelse af paradoksbegrebet. Vi har anvendt begrebet som en heuristisk tilgang til en detaljeret etnografisk analyse af datamaterialet med forståelsen af organisatoriske modsætningsfulde dynamikker for øje. Ud fra de empiriske data er det nærliggende at pege på, at begrebet om de autonome medarbejdere konstituerer ledelsesforståelsens afsæt på de to skoler. Når den formelle ledelse, sat overfor reformen, bevæger sig mod de nye styringsparadigmers ledelsesidealer om synlig, målsættende, strategisk og personalemæssig ledelse, så afspejles de flertydige processer i paradokser, deadlocks og omveje i ledelsesarbejdet. Hybridlederbegrebet har fået en vis gennemslagskraft i diskussionerne om offentlig ledelse, fordi begrebet indfanger flere dimensioner af ledelsesudøvelsen. Begrebet har imidlertid kun i begrænset omfang været brugt til at beskrive, hvordan hybridledelsen udøves i praksis (Hansen \& Voxsted 2012). Brugen af paradokser som analytisk linse i forskningsdesignet giver en mulighed for heuristisk at undersøge den mening, aktørerne tillægger spændinger, og hvordan de håndterer dem i praksis. Den etnografiske tilgang opretholder en følsomhed over for de indsamlede data, som giver mulighed for at se kompleksiteten i de professionelles flertydige arbejdsliv. På samme tid tillader paradokstilgangen det ekstra fokus, der tydeliggør spændinger i materialet. Ved at kombinere etnografi med et paradoksbegreb banes vejen for indsigt i de professionelles mikroprocesser og hermed i selve håndteringen af primus inter pares-ledelsen i praksis. Denne tilgang repræsenterer dermed en lovende mulighed for at opnå yderligere indsigt i NPM's forandringsprocesser ved at yde retfærdighed mod flertydighed og paradoksale arbejdsprocesser. 


\section{NOTER}

1 Begrebet professionelle anvendes efterfølgende i artiklens empiri om begge parter i samspillet ledelse/lærere. Lærerne omtales desuden i artiklen som medarbejdere.

2 For en nærmere introduktion til Tavistocktraditionen og den psykoanalytiske socialpsykologi, se Andersen (2006).

3 Vi vil ikke gå ind i en klassifikationsdiskussion om, hvorvidt gymnasielærere udgør en profession eller en semi-profession, da dette ikke har betydning for artiklens argumentation.

4 For en mere udtømmende redegørelse for undersøgelsens metodologi henvises til Juel Jacobsen (2009).

\section{ReferenCer}

Adler, Paul S., Seok-Woo Kwon \& Charles Heckscher (2008): Perspective - professional work: The emergence of collaborative community, i Organization Science, 19, 2, 359-376

Alvesson, Mats (2004): Knowledge Work and Knowledge: Intensive Firms, Oxford, Oxford University Press

Andersen, Linda Lundgaard (2006): Det indre og ydre liv på arbejde - en kritisk introduktion til Tavistock og den psykoanalytiske socialpsykologi. In Tidsskrift for arbejdsliv, (8), 3

Brint, Steven (1994): In an Age of Experts. The Changing Role of Professionals in Politics and Public Life, Princeton, NJ, Princeton University Press

Collins, Harry \& Richard Evans (2007): Rethinking Expertise. Chicago, Chicago University Press

Dahler-Larsen, Peter \& Hanne Katrine Krogstrup (Eds.) (2001): Tendenser i evaluering, Odense, Odense Universitetsforlag.

Farrel, Catherine \& Jonathan Morris (2003): The neo bureaucratic state: Professionals, managers and professional managers in schools: General practices and social work, i Organization, 10, 1, 129 -156
Gleerup, Jørgen og Finn Wiedemann (2001): De ungdomsgymnasiale læringskulturer, In Gymnasiepoedagogik, 18

Gottlieb, Susanne og Carsten Hornstrup (1998): Loereprocesser i gymnasieskolen. Udvikling i vidensorganisationer, Dansk kommunalkursus \& Den kommunale højskole i Danmark

Greenleaf, Robert K. (2003): The servant-leader within: A transformative path, New York, NY, Paulist Press

Hansen, Kristan Rune \& Søren Voxsted (2012): Ledere i første række, i Tidsskrift for Arbejdsliv, 14, 4, 68-83

Helin, Jenny et al. (2014): Process in How Process Does, i Jenny Helin, Tor Heines, Daniel Hjorth and Robin Holt: The Oxford Handbook of Process Philosophy \& Organization Studies, Oxford, Oxford University Press

Hjort, Katrin (red.) (2004): De professionelle: forskning i professioner og professionsuddannelser, Frederiksberg Roskilde Universitetsforlag Juel Jacobsen, Alice (2009): Professioner, paradokser og strategier i organisatorisk forandring, Ph.d.-afhandling. Aalborg, Institut for Læring og Filosofi, Aalborg Universitet

Juel Jacobsen, Alice (2014): Vignettes of interviews to enhance an ethnographic account, i Ethnography and Education, 9, 1, 35-50

Klausen, Kurt Klaudi (2006): Institutionsledelse, ledere, mellemledere, sjakbajser i det offentlige, København, Børsens Forlag

Kragh Jespersen, Peter (2005): Mellem profession og management, København, Handelshøjskolens Forlag

Kragh Jespersen, Peter (2012): Quality developement and professional autonomy in modern hospital fields, i Christine Teelken, Ewan Ferlie \& Mike Dent (red.), Leadership in the public sector: Promises and pittfalls, London, Routledge, 126-153

Lading, Åse (2005): Vi er jo kollegaer, ikke konkurrenter. Ph.d.-afhandling Odense, Syddansk Universitet

Larsen, Lars Thorup (2013): Guvernementalisering af velfærdsprofessionerne i Dansk sociologi nr. 3, 24, 38-61

Lewis, Marianne W. (2000): Exploring Paradox: Toward a more Comprehensive Guide, i Academy of Management Review, 25, 4, 760-776 
Noordegraaf, Mirko (2006): Professional Management of Professionals. Hybrid Organizations and Professional Managers in Care and Wellfare, i JanWillem Dyvendak, Trudie Knijn \& Monique Kremer (red.), Policy, People and the new Professional. Deprofessionalisation and re-professionalisation in care and welfare, Amsterdam, Amsterdam University Press, 181-193

Noordegraaf, Mirko (2007): From 'pure' to 'hybrid' professionalism: present-day professionalism in ambiguous public domains, $\mathrm{i}$ Administration Society, 39, 6, 761-785

Noordegraaf, Mirko (2012): The Making of Professional Public Leaders, Leadership as a practical myth, i Christine Teelken, Ewan Ferlie \& Mike Dent (red.), Leadership in the Public Sector, London, New York, Routledge, 214-236

Pedersen, Dorthe \& Camilla Sløk (2014): Reformpres og genopfindelse af gymnasieskolen, ledelse på potentialer i et postbureaukratisk styringsregime i Juelskjær, Malou, Hanne Knudsen, Justine Pors og Dorthe Staunæs, (red.), Ledelse af uddannelse, Samfundslitteratur, 103-133

Pedersen, Dorthe \& Matie Ryberg (2012): Ledelse og organisering i gymnasiet og VUC, København, Undervisningsministeriet

Pedersen, Dorthe \& Marie Ryberg (2013): Forankring af nye ledelses- og organiseringsprincipper i gymnasiet og VUC, København, Undervisningsministeriet

Power, Michael (1997): The Audit Society, Oxford University Press

Quinn, Robert E. \& Kim S. Cameron (1988): Paradox and transformation: Toward a theory of change in organization and management, Cambridge, Mass., Ballinger Publishing Co, $1-18$

Raae, Peter Henrik (2005): Troeghedens rationalitet: Gymnasiet og det forandrede forandringspres, Afhandling, Odense, Syddansk Universitet

Røvik, Kjell Arne (2007): Trender og translasjoner: Ideer som former det 21. århundrets organisasjon, Oslo, Universitetsforlaget

Schein, Edgar H. (1989): Organisationskultur og ledelse, Forlaget Valmuen
Senger, Ulla (2003): Organisatorisk loering og loererprofessionalisme i gymnasiet, Ph.d afhandling, Odense, Syddansk Universitet

Scott, Richard (2008): Lords of the dance: Professionals as institutional agents, i Organization Studies, 29, 2, 219-238

Smith, Jonathan \& Mike Osborne (Eds.) (2003), Interpretative Phenomenological Analysis Qualitative Psychology, Sage Publications

Smith, Wendy K. \& Mariane W. Lewis, (2011): Toward a theory of paradox: A dynamic equilibrium model of organizing, i Academy of Management, 36, 2, 381- 403

Spencer, Liz \& Alan Dale (1979), "Integration and Regulation in Organizations: A Contextual Approach" in Sociological Review, 27 (4).

Stacey, Ralph D. (2003): Complex responsive processes in organizations, New York, Routledge

Undervisningsministeriet (2004a): Lov om uddannelsen til studentereksamen (stx) (Gymnasieloven), (Lov nr. 95 og 96 af 18/02/2004)

Undervisningsministeriet (2004b): Lov om uddannelserne til højere handelseksamen ( $h h x$ ) og højere teknisk eksamen (htx), (Lov nr. 96 af 18/02/2004)

Undervisningsministeriet (2005): Vejledning til Bekendtgørelse om uddannelsen til studentereksamen, Undervisningsministeriet. Uddannelsesstyrelsen, j.nr. 2003-2423-9

Voxted, Søren (2008): Mellemlederrollen mellem profession og driftsledelse, i Camilla Sløk \& Kaspar Villadsen (red.): Velfoerdsledelse - I den selvstyrende velfoerdsstat, København, Hans Reitzels Forlag

Voxsted, Søren (2010): Førstelinjeledere i den kommunale sektor: En karakteristik af hybridlederen, Det Danske Ledelsesakademi, 6.-7. december, Aalborg, Aalborg Universitet

Wiedemann, Finn (2002), Skolekultur i gymnasiet - et kulturanalytisk casestudium af det almene gymnasium, HHX og HTX; Ph.d. afhandling, Odense, Syddansk Universitet 
Alice Juel Jacobsen, Ph.d., Adjunkt, Institut for Kommunikation og digitale medier, Aalborg Universitet, København

e-mail:ajja@hum.aau.dk

Anders Buch, Ph.d., Professor (mso), Institut for Læring og filosofi, Aalborg Universitet, København

e-mail: buch@learning.aau.dk 